\title{
A revolução que "não deu certo": senso comum e o impacto de 1917 no Brasil
}

\author{
Jersey Oliveira de Albuguerque
}

Resumo: $O$ artigo tem como objetivo, a partir de impressões comuns sobre a Revolução Russa, desmitificar alguns equívocos a seu respeito, resgatando a história do acontecimento e sua influência no Brasil. A impressão mais famosa é a de que a Revolução Russa "não deu certo"; por isso, a experiência teria apenas importância historiográfica. Até que ponto se pode considerar tais impressões válidas? Que ensinamentos essa experiência ainda pode proporcionar?

Palavras-chave: Revolução Russa. Movimento Operário Brasileiro. Senso Comum. Ideologia.

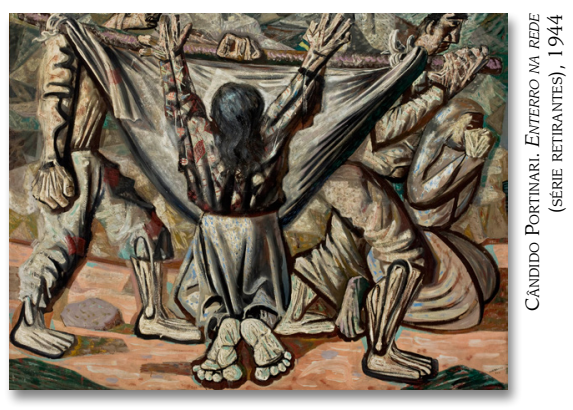

\section{The Revolution that "failed": common sense and 1017 impact in Brazil}

\footnotetext{
$\overline{\text { Jersey Oliveira de Albuguerque }}$

Mestrando em Sociologia (PPGS/ UECE). Monitor do Núcleo de Educação Popular 13 de Maio, responsável pela organização de cursos de formação básica para trabalhadores e estudantes. E-mail: jerseyoliveira@hotmail.com.
}

\begin{abstract}
The article aims, from common impressions on the Russian revolution, to demystify some misconceptions rescuing the history of the event and its influence in Brazil. Among these impressions the most famous is that the Russian Revolution "failed" and therefore this experience would only contain historiographical importance. To what extent can we consider these valid impressions? What lessons can this experience still provide us?
\end{abstract}

Keywords: Russian Revolution. Brazilian Worker Movement. Common Sense. Ideology.

$$
\text { RECEBIDO 30.03.2017 }
$$$$
\text { APROVADO 08.06.2017 }
$$ 


\section{INTRODUÇÃO}

Identificar até que ponto as impressões comuns sobre a Revolução Russa condizem com o que aconteceu nos eventos que abalaram o Brasil e o mundo em 1917, a partir da experiência de ensino deste autor em cursos sobre a temática, é objeto de nosso artigo. Será também de nosso interesse indicar as razões da construção de determinado senso comum sobre a Revolução.

A princípio, nos parece que a interpretação da experiência revolucionária sofreu diversas inflexões ideológicas não só por parte de representantes da classe dominante, mas de inúmeros militantes de esquerda que a superestimaram e/ou dogmatizaram a figura dos trabalhadores russos, do partido bolchevique e de suas lideranças (SACHES, 2011). Esta perspectiva foi usada para garantir, por exemplo, interesses do Estado burocratizado soviético pósSegunda Guerra nos conflitos geopolíticos, reprimindo, inclusive, revoluções que muito se assemelhavam ao que os bolcheviques realizaram em 1917. Também foi utilizada em âmbito acadêmico para blindar a Revolução de qualquer esforço crítico que permitisse realmente entender suas potencialidades e seus limites. Fazer a crítica ao senso comum e às posições ideológicas sobre a Revolução Russa torna-se central para fugir dessas armadilhas.

Inspirado por essas inquietações, desde 2011, o Núcleo de Estudos da Teoria Marxista, o NEMARX ${ }^{1}$, realiza minicursos acadêmicos e para bases estudantis e operárias sobre a Revolução Russa. O artigo nasceu da necessidade de dividir os acúmulos teóricos e pedagógicos desses cursos, bem como a dificuldade que tivemos em lidar com as interpretações do senso comum sobre o acontecimento de 1917. Foram realizados cinco cursos em locais diferentes: dois durante a disciplina de Ciência Política II do curso de Ciências Sociais da Universidade Estadual do Ceará, ao qual o grupo é filiado, um curso junto ao movimento estudantil da referida instituição, um com trabalhadores de várias categorias e o último num seminário acadêmico sobre marxismo.

1 O NEMARX é um grupo criado em 2011 por estudantes do curso de Ciências Sociais da Universidade Estadual do Ceará, que se dedica ao estudo da obra marxista e das revoluções sociais. Para saber mais a respeito, entrar em contato por meio do e-mail jerseyoliveira@hotmail.com. 
O trabalho parte das impressões sobre a Revolução Russa colocada pelos participantes dos minicursos. Inicialmente, nos debruçamos sobre dois mitos: 1) "a Revolução Russa não deu certo" e 2) "Revolução Russa e stalinismo são a mesma coisa". Já a terceira parte é voltada inteiramente para o mito de que "A Revolução não teve influência no Brasil", resgatando a experiência de 1917 no país e procurando as devidas lições. Com isso, pretendemos, levantar os fatos constitutivos do senso comum sobre o episódio e elucidar até que ponto são verdadeiros.

Dois conceitos guiarão nossa análise: "senso comum" e "ideologia". Antes de continuarmos, é necessário um rápido apontamento sobre estes e a relação com o nosso objeto.

Percebemos que os participantes dos cursos apresentavam uma impressão comum sobre a Revolução Russa, que se repetiu em vários momentos da pesquisa. Segundo Gramsci (2002), ${ }^{2}$ a tendência de construção do senso comum é marcada por problemáticas:

Nota 1 - Pela própria concepção do mundo, pertencemos sempre a um determinado grupo, precisamente o de todos os elementos sociais que partilham de um mesmo modo de pensar e de agir. Somos conformistas de algum conformismo, somos sempre homensmassa ou homens coletivos. O problema é o seguinte: qual é o tipo histórico do conformismo e do homem-massa do qual fazemos parte? Quando a concepção do mundo não é crítica e coerente, mas ocasional e desagregada, pertencemos simultaneamente a uma multiplicidade de homens massa, nossa própria personalidade é composta de uma maneira bizarra: nela se encontram elementos dos homens das cavernas e princípios da ciência mais moderna e progressista; preconceitos de todas

2 Há muitas interpretações sobre o senso comum em Antonio Gramsci e nos baseamos na citação do Caderno 11. De forma geral, existe uma interpretação desse conceito ligado à "visão de mundo" em que o caráter de consciência comum grupal toma destaque. Uma outra interpretação, porém, afirma isto e ainda insiste que essa visão de mundo em sociedades de classes tende a ser fragmentária e bizarra, sendo necessário um esforço para se romper com ela e elevar ao pensamento mais avançado do período. Esse último ponto de vista do conceito nos pareceu, durante a pesquisa, mais condizente com as narrativas observadas pelos participantes dos cursos, quando indagados sobre os eventos de 1917. 
as histórias passadas, grosseiramente localistas e instituições de uma futura filosofia que será própria do gênero humano mundialmente unificado. Criticar a própria concepção do mundo, portanto, significa torná-la unitária e coerente e elevá-la até o ponto atingido pelo pensamento mundial mais desenvolvido. (GRAMSCI, 2002, p. 253 - grifo nosso).

Em nossa experiência de pesquisa, esse caráter bizarro se revelou quando percebemos a extrema falta de informações históricas dos participantes sobre o evento da Revolução, acompanhada da absoluta certeza de que a mesma "não funcionou" ou "não deu certo". Isso nos levou a considerar que era preciso remontar com os participantes os processos pelos quais passou a Revolução Russa e seus impactos no Brasil assim como era preciso partir de uma crítica a essas concepções comuns que, segundo Gramsci (2002), pelo seu próprio processo de construção, mostram limites para a verdadeira compreensão dos fatos históricos.

Soma-se a essa dificuldade, a ideia de que a consciência social dominante de um período é a da classe dominante (MARX; ENGELS, 2012). A Revolução Russa foi claramente um movimento dos trabalhadores organizados contra a ordem capitalista. Esta ordem tem se mostrado refratária à iniciativa, insistentemente desqualificando-a, taxando-a pejorativamente. Assim, boa parte do senso comum sobre a Revolução é também marcada por esse ponto de vista dominante, que naturaliza uma visão negativa absoluta do fato.

Tal é a função da ideologia (MARX; ENGELS, 2012), uma relação social capitalista na forma de ideias. Suas características principais são: ocultar os fenômenos usando de meias verdades; universalizar pontos particulares da visão da classe dominante, como se fossem de toda a sociedade; inverter a lógica da produção social humana, criando a figura de "grandes heróis" (ou vilões), negando o carácter social dessa produção. Nas palavras dos autores:

As ideias dominantes em cada época são as ideias da classe dominante. As ideias da classe dominante nada mais são que a expressão ideal das relações sociais dominantes, as relações sociais dominantes concebidas como ideias; portanto, a expressão das relações 
que tornam uma classe a classe dominante, as ideias de sua dominação. (MARX; ENGELS, 2012, p. 48).

Atualmente, o combate no Brasil contra essa ideologia da Revolução encontra-se prejudicada pois, segundo Iasi (2013), somos herdeiros de um período de organização da classe trabalhadora, baseado em um projeto democrático popular ${ }^{3}$ que enfraqueceu a consciência de classe do proletariado. Este enfraquecimento não afetou apenas a capacidade de luta contra a burguesia brasileira, como também a memória dos grandes acontecimentos históricos que moldaram esta classe, a exemplo da Revolução Russa. Dela resultou um modo de lutar, baseado mais na representatividade do que em formas diretas de enfrentamento e/ou tomada de poder.

Mesmo agora, em que lutamos contra reformas ${ }^{4}$ que visam destruir o direito dos trabalhadores, discutir os eventos de 1917 aparece para o senso comum como um anacronismo, uma ideia absurda que "não tem e nunca teve relação com o movimento sindical brasileiro". Pretendemos com esse artigo ajudar na desmitificação desse debate.

\section{A REVOLUÇÃo QUE “NÃO DEU CERTO”}

Em todos os cursos ministrados, quando perguntávamos o que os participantes achavam da Revolução Russa, a primeira impressão era: "ela não deu certo né?", "uma revolução falha", "infelizmente a ideia não deu certo", "eles não souberam dividir os bens com o povo", dentre outras aparentadas. Ressaltavam também nessas concepções que foi um problema de "más" ideias colocadas em prática, em detrimento de "boas" ideias que funcionariam.

3 Projeto hegemonizado pelo Partido dos Trabalhadores (PT) e pela Central Única dos Trabalhadores (CUT). A tática seria a construção de uma frente sindical contra a burguesia que pressionaria a ordem e outra frente baseada na disputa institucional por dentro da ordem através das eleições. Esta última acabou tomando todo o espaço de ação na estratégia (IASI, 2013).

4 No momento em que escrevemos este artigo, o Governo Federal brasileiro tenta realizar a reforma trabalhista e previdenciária com o intuito de diminuir os gastos sociais para, segundo ele, "alavancar o crescimento". 
Nesse senso comum, detectamos a ausência de qualquer consideração das bases objetivas das mudanças revolucionárias que, em parte, escapam das escolhas racionais dos agentes envolvidos. No dizer de Marx (2012):

Do que se trata é de uma sociedade comunista não como se desenvolveu sobre as bases que lhe são próprias, mas, pelo contrário, tal como acaba de sair da sociedade capitalista; uma sociedade que, por consequência, em todos os aspectos, econômico, moral, intelectual, apresenta ainda os estigmas da antiga sociedade que a engendrou [...]. Mas esses defeitos são inevitáveis na primeira fase da sociedade comunista, tal como acaba de sair da sociedade capitalista, após um longo e doloroso parto. O direito nunca pode ser mais elevado que o estado econômico da sociedade e o grau de civilização que lhe corresponde (MARX, 2012, p. 30 - 33).

Sem levar em conta essas heranças, tanto as objetivas quanto as subjetivas, fica impossível ter uma clareza do campo de possibilidades e dos impasses que os trabalhadores russos e suas direções viveram. Nessa parte do curso, revisitávamos com os participantes os principais problemas que os bolcheviques enfrentaram nos primeiros anos pós-revolução e pedíamos para que tentassem se colocar no lugar daqueles e dessem soluções para os problemas que iam aparecendo. Dividíamos a turma em três grupos, cada um responsável por uma função de reprodução da sociedade (abastecimento, guerra e comunicação). Já o monitor do curso, interpretava a assembleia de comissários do povo russo que questionava as decisões dos grupos e expunha as necessidades. No decorrer do exercício, comparávamos as experiências com as ações executadas pelos trabalhadores soviéticos à época e que, na maioria das vezes, destoavam das que eram propostas pelos participantes.

Este exercício ajudou a quebrar a visão idealista da Revolução e a mostrar que esta é uma ação deveras difícil e complexa, porque a reprodução da sociedade não cessa, mesmo em meio a guerras. Em outras palavras, as pessoas continuam precisando de alimento, abrigo, água, etc. Vejamos quais foram os principais dilemas 
que deixaram a garantia dessas necessidades dramática na experiência soviética.

O primeiro impasse foi a própria Revolução ter assumido um caráter socialista e não apenas democrático-burguês (SACHS, 2011). ${ }^{5}$ Os próprios bolcheviques, até o início de 1917, não julgavam que ela aconteceria, porque a Rússia era tida como um dos países mais atrasados em termos de capitalismo. Ela não conhecia a luta entre a cidade e o campo nem o desenvolvimento de uma burguesia urbana independente dos interesses oligárquicos. Além disso, havia vivido quatro séculos de dominação mongol que deixou marcas profundas no país.

Outro fator marcante era o baixo grau de industrialização nas cidades russas, feitas a partir do Estado. Este desenvolvimento não obteve sucesso, tendo em vista a derrota na guerra contra o Japão (1904 - 1908) e na I Guerra Mundial (1914). Sobre a distribuição populacional no meio urbano e rural:

Na hora da revolução, em 1917, 80\% da população ainda vivia no campo. Num país de 140 milhões de habitantes, os camponeses representavam uma massa cinzenta, simbolizada pelo 'mujique'. Alheio à política e à organização social, cultivava a terra nos curtos meses de verão à base de uma agricultura arcaica. No longo inverno russo, dormia perto do fogão da cozinha, como encarnação da inércia. Hoje, já se esqueceu o que era uma aldeia russa antes da Revolução. Para se lembrar, bastaria voltar aos romances de um Tolstoi. Mas esse camponês, por outro lado, se distinguia por uma sede insaciável de terra. Desta terra que já havia sido das suas comunidades, do "mir", e que os grandes proprietários tinham se apossado com o apoio dos governos czaristas. O futuro da Rússia dependia, nas

5 Érico Sachs (1922- 1986). Judeu, nasceu em Viena e foi exilado ainda jovem para a URSS onde aprendeu sobre marxismo e se organizou nas oposições a Stalin. Devido a essas atividades, foi exilado para Áustria, Bélgica e, em seguida, para França onde teve contato com a Oposição ao Partido Comunista Alemão em Paris. Em 1939, foi obrigado a fugir da perseguição aos judeus e se refugiou no Brasil. Começou intenso trabalho como jornalista e fundou, nos anos 1960, a ORM POLOP (Política Operária), organização marxista que vai publicar diversos dos seus textos com o pseudônimo de Ernesto Martins (MEYER, 2010). 
palavras de Lênin, de quem iria dar a terra aos camponeses: se a burguesia ou o proletariado (SACHS, 2011, p. 120).

Em síntese: a maioria esmagadora da população russa vivia no campo e a Rússia era um pais de capitalismo atrasado com um desenvolvimento diferente do da Europa Ocidental. Completam esta base político-econômica para a Revolução Russa as características do operariado russo: jovem, rebelde, altamente concentrado (40 mil em algumas fábricas, como a Putilov), com capacidade de luta e sacrifício (SACHS, 2011). Esse operariado não tinha, no entanto, experiência alguma de autogestão nem conhecia nenhuma das instituições democráticas que Engels (apud SACHS, 2011) afirmara serem as condições mais favoráveis para o amadurecimento da organização socialista; desconhecia os sindicatos, por exemplo.

Essa característica foi muito importante para romper com o poder czarista, mesmo quando este quis assumir um Estado democrático através da Duma ${ }^{6}$ (entre fevereiro e outubro de 1917), para conter o ímpeto revolucionário. No entanto, quando os trabalhadores tomaram o poder pelas armas, isso viraria um entrave no que tange à construção de uma democracia de base operário-camponesa.

Assim, para os bolcheviques, a Revolução Russa apenas sobreviveria se os países de capitalismo avançado da Europa fizessem suas revoluções para compensar o atraso russo. E as greves que estouraram nesses países após 1917 (HOBSBAWM, 1997), algumas, inclusive, com caráter insurrecional, pareciam dar crédito a essa visão. Ao final de quatro anos de guerra civil e de tentativas de invasões por dezenas de exércitos financiados pelos aliados (EUA, Japão, dentre outros), chamados de exércitos brancos, tanto o país estava devastado economicamente como o ímpeto revolucionário havia deixado o continente europeu.

Nas palavras de Hobsbawm (1997):

6 Parlamento montado com membros eleitos representantes de várias frações de classe da Rússia. Logo que o Czar cai, em fevereiro, o Duma fica responsável por eleger o Governo Provisório. É dissolvido em outubro por representar os interesses da pequena burguesia na figura de Kerensky (REIS FILHO, 1999). 
[...] a revolução mundial, que justificou a decisão de Lenin de entregar a Rússia ao socialismo, não ocorreu, e com isso a Rússia soviética foi comprometida, por uma geração, com um isolamento empobrecido e atrasado. As opções para o seu desenvolvimento futuro estavam determinadas, ou pelo menos estreitamente circunscritas. [...]. Mesmo assim, a revolução sobreviveu. E o fez por três grandes razões: primeiro, possuía um instrumento de poder único, praticamente construtor de Estado, no centralizado e disciplinado Partido Comunista de 600 mil membros [...]. Segundo, era , de forma evidente, o único governo capaz de manter a Rússia integral como Estado - e disposto a tanto -, desfrutando, portanto, de considerável apoio de patriotas russos à parte isso, com os oficiais sem os quais o novo Exército Vermelho não poderia ser construído [...] a opção em 1917-1918 não era entre uma Rússia liberal democrática ou não liberal, mas entre a Rússia e a desintegração, que havia sido o destino de outros impérios arcaicos e derrotados, ou seja, a ÁustriaHungria e a Turquia. A terceira razão era que a revolução permitira ao campesinato tomar a terra. (HOBSBAWM, 1997, p. 71).

Apontar, como o senso comum identifica, que a "revolução não deu certo", sem ter em mente essas condições iniciais ou partindo do pressuposto que basta a "vontade individual" para que a história siga o curso desejado, só é possível apoiando-se em uma ocultação do processo revolucionário. Além disso, atualmente esquecem que não havia precedentes para guiar uma revolução como essa, pois nenhum Estado proletário havia durado muito tempo. E mais: esperava-se, como ainda hoje, que os trabalhadores russos provassem o acerto da teoria clássica marxista sem as bases que esta teoria afirmava como garantia de uma transição socialista, no caso, um alto desenvolvimento das forças produtivas sociais.

Essas dificuldades prepararão o terreno para o crescimento das tensões dentro da direção soviética, a contradição entre operários e camponeses, o recuo da Nova Política Econômica (NEP) ${ }^{7}$, a

7 Política posta em prática pela URSS, após 1921 até 1934, que consistia na 
consolidação da burocracia no país, a ascensão de Stalin e, posteriormente, o stalinismo.

\section{REVOLUÇÃO RUSSA E STALINISMO SÃO A “MESMA COISA”}

Depois de termos relembrado a complexidade do processo revolucionário e os problemas por que passou a Revolução Russa, discutíamos com os participantes os dilemas que os sovietes e os comunistas tiveram que encarar para sobreviver após a guerra civil. Era comum, havia o aparecimento das seguintes impressões nos participantes: "o stalinismo já deve ter começado aí então", "tá vendo, nessa situação eles tiveram que usar meios stalinistas para sobreviver" ou "o poder corrompe" etc.

Essa visão parte do princípio da construção singular da história por indivíduos e não por uma coletividade social em luta. Enxerga o sujeito singular, mas não vê os grupos sociais, as classes em disputa que determinam suas ações e as consequências destas. Na verdade, o mistério sobre Stalin e o stalinismo repousa na análise dos tensionamentos entre os diversos sujeitos da sociedade soviética, nas raízes da consolidação da burocracia (da qual Stalin foi mais produto que produtor) e dos conflitos internos do Comitê Central.

Comecemos pela diferenciação entre Stalin e stalinismo. Josef Stalin foi um membro do partido bolchevique, um dos mais "russos", segundo Lênin (apud SACHS, 2011), devido à sua origem camponesa e pobre, diferentemente da origem dos principais bolcheviques que vinham da intelligentsia russa. Stalinismo é a fase da ditadura pessoal de Stalin, fase em que ele perseguiu os membros da direção soviética, reprimiu a organização espontânea dos trabalhadores russos e transformou o partido em simples executor da vontade da burocracia. Este período começou apenas nos idos de 1934 e não pode ser estendido para o período anterior, o de consolidação da Revolução. Como veremos, em todas as fases anteriores da Revolução, Stalin conseguiu aprovar suas medidas (uma parte delas necessárias à continuação do regime)

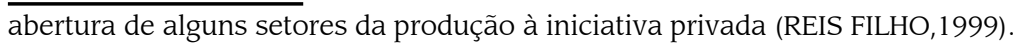


com o apoio da maioria da direção do partido e seguindo os ritos democráticos internos.

Apenas a universalização ideológica (MARX; ENGELS, 2012) de um ponto de vista particular sobre a Revolução a todo o seu processo é capaz de reduzir a rica experiência soviética a apenas uma das fases, a que já marca a sua deformação. Tal afirmação acaba apenas por reforçar a primeira impressão que demonstramos: a da falência da iniciativa. Por isso, cremos ser necessário entender as bases que permitiram que um agente aparentemente medíocre (Stalin) tomasse tamanha importância na história soviética. Este processo estará intimamente ligado a outros impasses dramáticos pelos quais passou a Revolução.

\subsection{O CONFLITO ENTRE CAMPONESES E OPERÁRIOS}

Esta contradição teve início ao fim da guerra civil (1917 1921). Durante essa guerra, houve coleta compulsória de grãos dos camponeses pelo governo. Estes aceitavam a requisição, porque era a Revolução que lhes assegurava a terra. Se derrotada, os camponeses perderiam esse bem. Terminada a guerra civil, a situação haveria de mudar e acabaria a necessidade de requisição forçada. De início, o governo propôs a troca dos grãos por outras mercadorias; porém, com a produção industrial equivalente a um quinto do que era antes da guerra, não havia como garantir esta troca.

O campo ameaçou cortar o suprimento das cidades e isso colocaria a Revolução em risco. Lênin, então, propôs a NEP, que consistia numa política para acalmar os camponeses, mas também significava retroceder em relação à planificação socialista, restabelecendo uma parte da política de mercado. Isso mesmo: para salvar a Revolução isolada, era preciso resgatar parte do mercado privado abolido nos primeiros anos.

Sobre o realismo dos bolcheviques quanto à manutenção da Revolução, Hobsbawm (1997) nos diz que:

[...] ao contrário da mitologia da Guerra Fria, que via Lenin essencialmente como organizador de golpes, a única vantagem real com que ele e os bolcheviques contavam era a 
capacidade de reconhecer o que as massas queriam; de conduzir, por assim dizer, por saber seguir. Quando, por exemplo, ele reconheceu, ao contrário do programa socialista, os camponeses queriam uma divisão da terra em fazendas familiares, não hesitou num instante em comprometer os bolcheviques com essa forma de individualismo econômico. (HOBSBAWM, 1997, p. 68).

Esses recuos necessários para que a Revolução resistisse geravam novas contradições que acabaram por travar o retorno ao desenvolvimento socialista no campo e ainda afetavam os operários da cidade. Vejamos as medidas que constituíam a NEP. A primeira delas era o fim das requisições forçadas no campo e sua troca por dinheiro. Para que isto ocorresse, o Estado reprivatizou setores industriais que produziam os insumos que os camponeses precisavam. Mesmo que isso chegasse a representar apenas 20\% da indústria (sendo o restante estatal, principalmente os setores primários e de energia), era essencial para o objetivo da NEP.

É conhecida a tentativa de Lênin que desesperadamente procurara investidores privados estrangeiros para a Rússia. A maioria deles, pressionada por acordos envolvendo os EUA e a Inglaterra, recusou a oferta para que a Revolução se estrangulasse (SACHS, 2011). Os que aceitaram ressuscitaram uma nova burguesia nas cidades, de pequena proporção, chamada de "homens da NEP", que respondia ao Governo, mas tinha liberdade de explorar os trabalhadores e ter seus próprios planos de restabelecimento do capitalismo na Rússia.

Em consequência dessas medidas, mudou-se a estrutura de classes no campo. A distribuição de terra não tinha como ser igualitária, pois inevitavelmente alguns camponeses ficaram com terras melhores que outros. No início, os bolcheviques se apoiavam nos mujiques (camponeses pobres), porém o que estes produziam apenas servia para consumo familiar, não sobrando para a troca com a cidade. Os bolcheviques, então, foram obrigados a se apoiarem nos agricultores médios e nos Kulaks, camponeses ricos que utilizavam força de trabalho assalariada. Por fim, para incentivar a produção, também foi permitido a eles arrendar as terras menos produtivas (SACHS, 2011). 
Ao adotar tais medidas, o Estado soviético se viu pressionado, não a superar, mas a reconstituir as bases econômicas pré-revolucionárias. No entanto, na penúria daquela república, qualquer benesse para uma classe ocorria em detrimento de outra. Preços mais caros dos grãos, que agradavam aos Kulaks, significava pão mais caro nas cidades e fome para os trabalhadores. Apesar de aceitarem a NEP, a maioria dos bolcheviques não tinha consciência ainda das contradições que ela criaria. Sabiam que este era um recuo necessário, mas não sabiam quando nem como a NEP deveria ser superada. As discussões e as medidas para garantir a NEP vão dar origem às facções dentro do partido e à oposição entre Trotsky e Stalin.

\subsection{DUAS FACETAS DOS BOLCHEVIQUES: TROTSKY E STALIN}

Trotsky foi um grande dirigente bolchevique. Teve participação fundamental na montagem do exército vermelho, na tomada do Palácio de Inverno e na guerra civil. Porém, após a consolidação do poder e decepcionado com o fracasso da Revolução na Alemanha em 1923,8 pelo qual culpou a direção bolchevique, Trostsky assumiu posições idealistas na condução do governo. Estas acabaram isolando-o dos trabalhadores russos e da direção do partido, fortalecendo indiretamente as posições do pragmático Stalin, que representou a outra face da forma soviética de resolver as dificuldades econômicas (SACHS, 2011).

8 Em 1923, houve tentativa de um levante na Alemanha puxado por uma ala comunista do Partido Social-Democrata alemão. A tentativa fracassou principalmente pelo esponteneísmo e suas lideranças foram cassadas, a exemplo de Rosa Luxemburgo que foi assassinada. Para Trotsky, no entanto, o problema foi que o governo soviético não se empenhou o suficiente para concretizar a revolução. Segundo Sachs (2011), essa interpretação estava equivocada, pois ignorava as condições da luta do Partido Social-Democrata alemão e suas divisões, o que acabou precipitando a tentativa de revolução sem as forças necessárias para sua concretização. O movimento foi esmagado e o vácuo deixado pelos comunistas na política foi assumido depois pelo nacionalismo nazista (SACHS, 2011). Para mais detalhes sobre a tentativa da revolução alemã, ver Loureiro (2005). 
Trotsky já havia demonstrado esses traços idealistas em pelo menos duas polêmicas com o resto da direção bolchevique e, principalmente, contra Lênin. Posteriormente, Stalin resgatará as posições de Trotsky nesses conflitos e as colocará em prática. A primeira polêmica foi em relação ao nível de estatização da economia. Trostsky defendia 100\% de estatização pós-guerra civil e Lenin, pelos motivos já citados, era contra, afirmando que o Estado não tinha capacidade para suprir sozinho a industrialização. Trotsky perdeu nas votações e o sucesso da NEP comprovou que estava equivocado.

A segunda polêmica teve relação com a organização das fábricas pelos trabalhadores. Iniciada por Osinsky e Sapronov, ${ }^{9}$ constituiu-se num movimento contra a reestruturação das lideranças de um homem só nas fábricas, que estava sendo colocada em prática pelo Estado (SACHS, 2011). Até então, as fábricas eram dirigidas por conselhos de operários, porém, devido ao atraso político da classe operária russa e à sua carência de técnicos e profissionais (muitos deles mortos durante a guerra civil), a produção das fábricas estancava. Kollontai ${ }^{10}$ defendeu que fosse dada a direção para os sindicatos. Trotsky sugeriu o extremo oposto: a militarização do trabalho e a estatização dos sindicatos para a garantia da produção. Lênin e o resto da direção foram contra aos dois extremos. Primeiro, porque os sindicatos eram novos e inexperientes; segundo, porque a organização dos trabalhadores devia suplantar o Estado num período posterior e não era estatizando-os e militarizando-os que isso seria cultivado. A revolta dos marinheiros de Kronstadt"11 pôs por terra as ideias de Trotsky, que foi derrotado mais uma vez.

9 Membros da direção bolchevique.

10 Alexandra Mikháilovna (1872-1952). Filha de um general tzarista, tornouse revolucionária. Obrigada a procurar segurança no exílio em 1908, regressou para participar na Revolução Bolchevique. Em 1920, foi nomeada comissária do povo da Previdência Social e, em anos posteriores, ministra e embaixadora na Noruega, no México e na Suécia (REED, 1967).

11 Revolta dos marinheiros em 1921 contra a péssima condição de vida pósguerra civil e o centralismo bolchevique nas decisões do governo. Estes tinham apoiado fortemente a Revolução de 1917. 
Essas divergências foram resolvidas por meio de procedimentos da democracia interna do partido, sem criação de cisões sérias. Isso mudou após a morte de Lênin e com as disputas em torno da efetivação da NEP. Não se deve esquecer que quem assumiu o poder no lugar de Lênin foi Stalin, que não foi indicação do antigo dirigente. Este havia chamado Trotsky para substitui-lo, o qual recusou, talvez devido às derrotas que sofrera. Mais importante do que imaginar se o resultado mudaria com a direção de Trotsky, é significativo investigar qual foi o contexto em que Trostsky foi isolado e Stalin se consolidou com o apoio da maioria do partido.

O ano de 1927 - 1928 foi decisivo (HOBSBAWM, 1997; SACHS, 2011). Os camponeses ficaram muito fortalecidos com as concessões fornecidas pelo Estado e se negavam a seguir a tabela de preços definida pelo governo dos operários. Estes passavam fome nas cidades e se revoltavam com a direção do governo, estourando greves e motins. Trotsky montou uma oposição com uma minoria bolchevique apoiada por técnicos de média patente, herdeiros da intelligentsia russa. Em suas reivindicações, estava o aumento dos salários operários, porém, a um preço que fecharia as empresas menos rentáveis (SACHS, 2011). Porém, qual empresa era rentável em meio à crise soviética? Os trabalhadores viram isso como ameaça a seus empregos e abandonaram Trostsky. O que indignou a direção bolchevique foi a forma como este dirigente conduziu a luta pela maioria dos votos dentro do partido:

A luta interna, desta vez, foi caracterizada por uma violência inédita. A oposição rompeu com as regras do jogo, procurando mobilizar o descontentamento latente das massas fora do Partido. O que mais irritou os velhos bolcheviques foram os slogans oposicionistas que falavam de uma "aliança dos burocratas, homens da NEP e os Kulaks" para reestabelecer o capitalismo na União Soviética. Os velhos revolucionários (que estavam incluídos entre os "burocratas"), que haviam lutado pela revolução, que toleravam a NEP por motivos de força maior e que estavam procurando um caminho para superá-la, não perdoaram Trotsky esses métodos de luta interna. Davam carta branca a Stalin para que aplicasse, por sua vez, medidas até então apenas usadas 
contra os inimigos de classe. Seria, todavia, totalmente irrealista querer explicar a derrota da oposição unida pelos métodos duvidosos do Secretário Geral. Este teve atrás de si a maioria do Partido e era justamente por esse fato que podia usar de métodos abertamente discriminatório e repressivos contra a oposição. E ele teve cuidado de lançar mão desses métodos apenas depois de a oposição ter ficado desmoralizada e isolada no seio do Partido. (SACHS, 2011, p. 146 - 147).

Assim, Stalin se colocou contra o exílio de Trotsky da URSS, proposto pelo partido. Então, usou da neutralização da oposição para se concentrar no problema que esta omitira em suas reivindicações: o de como resolver o impasse no campo. Momentos radicais exigem ações radicais: a NEP alcançara seu limite como política de transição e, para o aprofundamento das bases socialistas do regime, era necessário o extermínio da propriedade privada no campo, que chantageava as cidades com o alto preço dos alimentos. Stalin propôs a coletivização forçada. Conseguiu aprovação do partido mesmo com a resistência de dirigentes ligados aos camponeses como Bukharim ${ }^{12}$ que propunha um "socialismo a passo de lesma" para evitar o derramamento de sangue (SACHS, 2011).

Apenas Stalin assumiu os riscos da medida e foi o único que levou a herança da NEP até as últimas consequências. Em quatro anos, todo o interior da Rússia vira a propriedade Kulak dar lugar a colskoses e sovkoses (fazendas estatais). Milhões de camponeses que resistiram foram mandados para a Sibéria. Outra medida não teria conseguido, em tão pouco tempo, resolver o problema nessa velocidade. O governo também não dispunha de recursos para convencer os camponeses antes do colapso. O círculo vicioso de dependência dos camponeses ricos apenas poderia ser quebrado por meios extraeconômicos. Importante frisar que esta não tem

12 Nikolái Ivánovitch Bukharine (1988-1938). Bolchevique desde 1906, destacou-se como propagandista e organizador. Exilado a partir de 1911, editou durante algum tempo, em Nova York, juntamente com Trotsky, o jornal socialista russo Nóvi Mir. Foi eleito para o comitê central bolchevique e, depois da Revolução de outubro, se tornou editor do Pravda. Várias vezes membro da oposição de esquerda e de direita, foi vítima da depuração de Stalin em 1938 (REED, 1967). 
que ser uma ação necessária em qualquer revolução, pois outras revoluções resolveram a questão de outra forma (HOBSBAWM, 1997), mas aqui trata-se das condições russas daquele período que não devem ser tomadas como regra dogmática.

Terminada essa fase, em meados de 1930, a produção industrial atingiu o nível pré-guerra e, quatro anos depois, ela permitiu o aumento vertiginoso da indústria a partir dos planos quinquenais. As condições dos operários melhoraram e começaram a ser formados, em grande escala, técnicos em diversas áreas que deveriam ser o bastião da retomada socialista. Dez anos depois, esse desenvolvimento permitiu vencer o imperialismo mais agressivo da Europa na Segunda Guerra: a Alemanha nazista. A coletivização forçada, depois chamada de "acumulação socialista primitiva", e seu sucesso acabaram com as oposições. Mesmo os aliados de Trostsky se colocaram a serviço de Stalin e o trotskismo virou apenas "bode expiatório" para as perseguições posteriores do stalinismo.

Só podemos entender completamente essas figuras históricas e sua importância na conjuntura da época, relacionando-as com as tensões entre as classes sociais à época. Stalin e Trostsky foram produtos das contradições russas, cada um ressaltando a polarização entre idealismo e pragmatismo. Os participantes dos cursos que ministramos ficavam atônitos com a quebra da dicotomia entre essas duas personalidades proveniente do senso comum, marcada pela imagem de um Trotsky "injustiçado" e de um Stalin "assassino-ditador". Também ficaram abalados ao conhecerem as sérias decisões de uma forma de economia não centralizada no lucro e suas consequências devastadoras para algumas classes. Nesse momento, alguns perguntavam onde estiveram os sovietes nesse processo todo e por que as grandes decisões ficaram à mercê do partido. É o que investigaremos agora.

\subsection{OS SOVIETES, A BUROCRACIA E O STALINISMO}

Durante o curso, quando perguntados sobre o que sabiam sobre os sovietes, as impressões dos participantes eram muito positivas. Os sovietes apareciam como representantes da vontade dos 
trabalhadores, que, por causa do stalinismo, haviam sido traídos. É comum, nas análises do senso comum, o trabalhador aparecer somente como sujeito passivo da História, à mercê de lideranças carismáticas. Parece não haver o questionamento contrário, a saber: que tipo de ser coletivo de classe na Rússia determinou o aparecimento de uma tutela estatal que se desenvolveu como stalinismo? Para explicitar essa questão no curso, expúnhamos sobre as bases em que se formou a burocracia soviética. Esta, em seu desenvolvimento, substituiu a capacidade de direção do operariado russo. Além disso, apoiou Stalin que, sem ela, não teria alçado tanta influência no mando do governo (SACHS, 2011). Para entender o surgimento da burocracia russa, precisamos relembrar o papel dos próprios sovietes.

Estes haviam se formado já em 1905, como resultado da primeira Revolução Russa. ${ }^{13}$ Representavam a capacidade autônoma de organização dos trabalhadores que deveria substituir o Estado na sociedade dos produtores associados, posterior ao socialismo. Marx (2014) já havia apontado que era na sociedade capitalista que se desenvolviam as formas de organização dos trabalhadores que substituiriam o Estado como forma de dominação de uma classe sobre a outra.

Seria no organizar-se contra a ordem que os proletários criariam uma forma para além da ordem. O problema era que este preparo fora feito numa sociedade capitalista deveras atrasada até em relação às formas democráticas de luta. Somaram-se a isso intensos anos de guerra civil que vitimaram os operários de consciência mais avançada, forçando os que restaram a ocupar postos avançados no governo, se afastando do cotidiano do local de trabalho.

Era de se esperar que os sovietes, nessas circunstâncias, não conseguissem garantir a direção da produção de bens necessários à reprodução da vida soviética. Faltavam técnicos, profissionais,

13 Em 1905, uma passeata puxada pela Igreja Ortodoxa russa junto aos trabalhadores foi alvejada às portas do Palácio de Inverno. A revolta que se seguiu deu origem à Primeira Revolução Russa que tomou o controle das cidades. O movimento, por seu caráter descentralizado e espontâneo, foi derrotado, porém foi a base de criação dos sovietes (REIS FILHO, 1999). 
pedagogos, engenheiros e chefes militares. O protagonismo operário devia ser fomentado pelo Estado soviético (LENIN, 1983), que não dispunha de tempo para esperar o processo e tinha que garantir a Revolução no presente. Nessa conjuntura, a utilização da burocracia (czarista) anterior à Revolução não foi opção, mas necessidade.

A importância desta burocracia na guerra civil e nos anos posteriores era tão clara que até Trotsky defendia abertamente que ela devia ter privilégios, o que lhe custou a alcunha de "pai dos burocratas" feita por Stalin. Lênin colocava a questão em outro plano: dizia que o problema não era a burocracia, era saber, na verdade, quem controlava quem; se os trabalhadores a controlavam ou se o contrário (LÊNIN apud SACHS, 2011). Isso ficava mais complicado, pois os novos burocratas oriundos do partido e dos sovietes conviviam com os antigos burocratas e acabavam por aprender os vícios dos seus pares.

Para dirigir a burocracia, os trabalhadores deviam amadurecer, se formar, se capacitar, sair do perigo da fome e da miséria para poderem se concentrar em suas tarefas de auto-organização, visando suplantar o Estado. Esse nível foi alcançado em meados de 1934 (SACHS, 2011). A URSS havia formado milhares de novos técnicos nas escolas, professores vermelhos, identificados com a Revolução e oriundos da classe trabalhadora. O nível cultural aumentou, com a diminuição dos analfabetos e a popularização da arte. Era natural, nessas condições, que os trabalhadores russos exigissem a volta dos padrões de democracia operária dos primeiros anos de Revolução. E nisso não havia hostilidade à pessoa de Stalin; pelo contrário, se acreditava que a direção do partido, que foi vitoriosa em melhorar a condição de vida do povo russo após tanto sofrimento, encamparia também essa abertura das decisões. Porém, chegada a hora, a burocracia soviética e Stalin não permitiram:

Não é raro na história do movimento operário (e na História em geral) que uma liderança criada em determinada época e sob determinadas condições de luta falhe e fique superada quando mudam as épocas e as condições. Raros, porém, são os casos em que 
tais lideranças tenham consciência das suas limitações(...)Tendo se tornado dirigente máximo do partido numa época crítica, e completada que estava a Revolução de Outubro com a socialização do campo e o início da economia planificada, não percebeu, ou não quis perceber, que sua ação na liderança do Partido e do Estado tinha gerado situações e condições novas, que requeriam novos métodos (...) A ditadura pessoal, por sua vez, tinha de marcar profundamente toda a estrutura da sociedade soviética. Apesar dos futuros progressos econômicos a superestrutura política e ideológica regrediu. (SACHS, 2011, p.159).

Apenas nesses termos que se pode falar em stalinismo. $O$ primeiro alvo foi o partido, através de processos forjados que acusavam toda a velha guarda bolchevique de ser formada por agentes a serviço da Alemanha ou do Japão. O que importa aqui é a base para estas ações. Com certeza, a marca pessoal de Stalin, pragmático e avesso à teoria marxista, teve importância, porém só o fator pessoal não é suficiente. Lênin afirmara que a Revolução Russa deveria recorrer, em última instância, a métodos bárbaros para superar a tradição bárbara do país (LENIN apud SACHS, 2011). O que era para ser exceção acabou virando regra. Parece-nos que as condições em que ocorreu a Revolução, isolada de outros países, favoreceram a que métodos imediatistas ganhassem força e se tornassem determinantes no stalinismo.

Sem levar em conta essas condições, torna-se fácil para o senso comum afirmar que toda a Revolução Russa é stalinismo. Com isso, se apagam as fases por que passou a Revolução, os dilemas e a reflexão necessária para se aventurar novamente no plano da tomada do poder. Esta é esquecida em meio a jargões universalizantes que descartam a ação revolucionária como saída atual e histórica para os problemas dos trabalhadores, que não parecem tão distantes assim da Rússia de 1917. Resta ainda mais um elemento dessas impressões sobre a Revolução que muito nos interessa, a saber: se houve ou não impacto desse evento histórico no movimento operário brasileiro e, se houve, por que a Revolução não está presente na memória coletiva das lutas dos trabalhadores brasileiros. 


\section{E O BRASIL: GREVE GERAL E ESQUECIMENTO}

Os participantes dos cursos, quando perguntados sobre as possíveis influências da Revolução no Brasil, simplesmente não tinham o que dizer. Ao contrário das impressões anteriores, que tínhamos que desmontar através de dinâmicas e exposições, aqui tínhamos que começar do zero. A nosso ver, esse "desconhecimento" por parte do senso comum tem sua raiz no desconhecimento da história do movimento operário brasileiro.

Quando indagávamos sobre o que sabiam desse último, apareciam impressões que identificavam o movimento operário apenas com a luta sindical dos anos 1980. Outras afirmações também foram: "o brasileiro não sabe lutar", "temos uma tradição muito passiva por causa do nosso passado", "é um povo frouxo" dentre outras aparentadas. Para contrapor essa visão, explanávamos sobre o início da organização operária nos fins do século XIX até a grande greve geral de 1917 no país. Seguiremos também esse caminho em nossa explanação.

De forma geral, a Revolução Russa vai influenciar de três formas o início da organização dos trabalhadores brasileiros: 1) na criação das primeiras leis sociais trabalhistas; 2) na oposição à imprensa da época, que deturpava tanto os eventos de 1917 na Rússia quanto as lutas que influenciaram no Brasil; e 3) a passagem da organização hegemônica dos trabalhadores de base anarquista para comunista. Comentaremos prioritariamente a construção da primeira marca.

\section{GREVE GERAL DE 1917}

Em 1917, a I Guerra Mundial chegava ao seu ponto crítico. Explodiam em várias nações greves, exércitos amotinadas, passeatas pela paz e etc. A economia brasileira sentia os efeitos da guerra em sua produção industrial (BANDEIRA; MELO; ANDRADE, 1980). Até a guerra, a maioria dos bens manufaturados consumidos no Brasil vinha de fora, tendo a indústria nacional participação de apenas 5\% na produção. Com o bloqueio de parte dos produtos dos países belicosos, estes artigos tinham que ser produzidos aqui. Assim, entre 1914 e 1919, a produção industrial nacional dobrou 
e o proletariado brasileiro alcançou o considerável número de 200 mil trabalhadores.

Já os empresários viveram uma época de bonança, principalmente com os "negócios de guerra": café, açúcar, algodão e borracha. Os compradores internacionais desses produtos investiam no país. Inglaterra, EUA e Itália ganhavam duas vezes, utilizando a barata força de trabalho brasileira e comercializando os produtos extraídos aqui. Era o imperialismo do qual já falara Lênin (2012).

A classe trabalhadora brasileira, por sua vez, passava por precárias condições de vida (BANDEIRA; MELO; ANDRADE, 1980). Os artigos de sobrevivência eram muito caros perante os baixíssimos salários e se fazia uso intensivo da força de trabalho feminina e infantil. Os patrões, às vezes, seguravam o pagamento dos trabalhadores, como na época em que a gripe espanhola se espalhou, trazida pelos soldados brasileiros que lutaram na Primeira Guerra, e os empregadores afirmavam terem tido prejuízo com a falta de empregados doentes. Além disso, obrigavam os operários a comprarem em seus armazéns, diminuindo o poder de aquisição do salário. A jornada diária real, em algumas fábricas, chegava a 14 horas, inclusive no sábado. Esses fatores, somados ao aumento constante do custo dos víveres, faziam o tempo de vida médio do operário girar em torno de 25 anos (BANDEIRA; MELO; ANDRADE, 1980).

O ano de 1917 surpreendeu pela quantidade de revoltas operárias no Brasil, a partir do impacto da Revolução Russa e da piora das condições de trabalho e de vida. A classe trabalhadora brasileira já existia desde início dos século XVIII, formada pelos primeiros assalariados do regime escravocrata: alfaiates, mestres, aprendizes, pescadores, tecelões, tipógrafos, dentre outros (BANDEIRA; MELO; ANDRADE, 1980). Receberam influência direta dos grandes acontecimentos da Europa, como o socialismo utópico, a criação da I Internacional e da Comuna de Paris, tendo, inclusive, acolhido exilados dessa última. Já haviam participado de diversas revoltas contra a ordem como a Inconfidência Baiana (1790), a Revolução Praieira (1850), um motim contra o transporte de escravos no Ceará por pescadores, lutas pela República, apenas para citar alguns fatos. 
Algumas categorias se organizavam em uniões e ligas, o que viria a ser o germe dos sindicatos. Uma de suas principais armas de mobilização eram os periódicos e centenas de pequenos jornais como O Socialista (Salvador), O Operário (Fortaleza), O Avanti (São Paulo) e O Nilista (Rio de Janeiro), apenas dentre tantos. Esses periódicos informavam os trabalhadores e conclamavam para as primeiras grandes lutas políticas que giravam em torno do direito de protestar no $1^{\circ}$ de Maio.

Em 1905, realizaram uma campanha nacional de solidariedade aos trabalhadores russos massacrados pelo czarismo. Em 1906, no II Congresso Operário Brasileiro, criaram a primeira Confederação Sindical Operária (COB). No mesmo ano, saiu a primeira lei que legalizava os sindicatos, mas as organizações sindicais decidiram continuar na ilegalidade para fugir ao controle do governo, mostrando a tenacidade do movimento àquela época.

Assim, a classe trabalhadora brasileira foi beneficiada pela experiência já cultivada na Europa de organização dos trabalhadores, que desembarcou aqui com os primeiros imigrantes operários e também com a política imperialista (LENIN, 2012) que abria as portas da revolução também para o "elo mais fraco", ou seja, os países dominados e atrasados como a Rússia e o Brasil. Mas por que aqui as revoltas de 1917 não se transformaram em revolução? A resposta estaria na própria estratégia das organizações dos trabalhadores, que tinham princípios anarquistas.

Os anarquistas foram a primeira liderança corajosa da classe brasileira (BANDEIRA; MELO; ANDRADE, 1980). Foram torturados, enviados para a "Sibéria brasileira" (o Acre), enfrentaram as prisões e foram perseguidos. Sem os grandes organizadores do anarcossindicalismo e do anarcocomunismo, não teríamos tido as primeiras conquistas de direitos no país. Porém, a estratégia utilizada restringia-se à luta pela greve geral como forma de ganho de direitos econômicos. O passo seguinte, a tomada de poder, não era considerada, pois qualquer forma de controle da produção que passasse pelo Estado, como fizeram os bolcheviques, estava fadada ao fracasso. Para os anarquistas, qualquer forma de opressão que se apoiasse no Estado significava o retorno a um grilhão que a humanidade deveria superar. Assim: 
[...] As massa estavam sob a liderança dos anarquistas que, embora heroicos e denodadamente combativos, não possuíam a organização necessária para destruir o regime latinfundiário-burguês [...]. As grandes greves e agitações de massa do período de 1917/1920 puseram a nu a incapacidade teórica, política e orgânica do anarquismo para resolver todos os problemas de direção de um movimento revolucionário de envergadura histórica quando a situação objetiva do País (em conexão com a situação mundial criada pela guerra imperialista de 1914/1918 e pela vitória da Revolução operário e camponesa na Rússia) abrira perspectivas favoráveis a radicais transformações na ordem política e social dominante (PEREIRA apud BANDEIRA; MELO; ANDRADE, 1980, p. 51).

E qual seria essa situação objetiva? Revoltas, greves, insurreições, lutas de rua, ingovernabilidade. Isso prova que, independente das limitações do movimento à época, diferentemente do que pensa o senso comum, a classe trabalhadora brasileira não tem uma marca natural de passividade ou amedrontamento. No ano de 1917, apenas na cidade de São Paulo, houve 14 greves, uma destas estadual e outra que se transformou em greve geral por todo o pais.

Movimentos semelhantes acontecerem em Pernambuco, Mato Grosso, Bahia, Minas Gerais, Pará e Rio de Janeiro. Neste último, os trabalhadores tentaram junto com os marinheiros tomar o governo (que à época funcionava no Rio de Janeiro) e conclamar o "Soviete do Rio". A tentativa foi descoberta em cima da hora do ataque, mas várias fábricas aderiram ao chamado na hora combinada e pararam suas atividades. Isso deixou o governo geral em pânico, procurando uma forma de acalmar os subversivos (BANDEIRA; MELO; ANDRADE, 1980).

O movimento de maior proporção foi o de julho de 1917, em São Paulo. As fábricas e os estabelecimentos fecharam. Em uma semana, todo o estado estava parado, inclusive o transporte. Em alguns bairros, a população demonstrava o apoio ao movimento, construindo barricadas e as trabalhadoras do lar molhavam as ruas com sabão derretido para que os cavalos da polícia 
escorregassem. As autoridades, incapazes de conter os motins apenas com a violência, cansaram e perderam a moral. O governo, então, fugiu da capital.

Os trabalhadores assumiram e apenas permitiam que o leite e a carne chegassem aos hospitais. Depois que atracaram navios da Marinha no Porto de Santos, recomeçou uma tentativa de retomar à cidade por parte das forças policiais. A revolta dos trabalhadores chegou ao ápice depois da morte do sapateiro Martínez, ${ }^{14}$ numa batida policial. Os grevistas seguiram numa grande procissão até sua casa e, após levar o caixão ao cemitério, operaram saques em diversos estabelecimentos. O contingente faminto e desesperado, formado também por mulheres e crianças, forçou os grandes empresários da cidade, a imprensa burguesa e o governo a se reunirem com uma representação de trabalhadores na sede do jornal O Estado de São Paulo (BANDEIRA; MELO; ANDRADE,1980).

No acordo assinado entre as partes, os patrões se comprometeram a controlar os preços dos produtos de primeira necessidade e a garantir o direito de reunião dos operários, que nenhum líder fosse preso pela greve e que se realizassem estudos sobre as demais reivindicações, que incluíam maior cuidado com o trabalho infantil e feminino. Findada a greve, governo e empresários, com exceção de aumento salarial de 30\%, não cumpriram nenhum dos outros acordos e a polícia ainda prendeu e deportou os principais dirigentes trabalhistas. A revolta acabou em meio a sangue e em meio ao apelo de nacionalismo do governo, motivado pelo naufrágio do navio Paraná da Marinha, atacado pelos alemães no oceano Atlântico. O movimento de greves pelo país durou até dezembro de 1917 e esmoreceu. Seria o seu fim?

Em 1919, os preços dos alimentos aumentaram mais uma vez, anulando os ganhos salariais de 1917. A revolução saía da Rússia e parecia se espalhar para outros países da Europa, incentivando as organizações trabalhistas no Brasil. O chamado para a nova

14 Em 9 de junho de 1917, na cidade de São Paulo, Antônio Igneguez Martínez estava em frente à fábrica Mariângela, realizando protesto com outros trabalhadores. A polícia iniciou tentativa de expulsão dos operários do local. Houve troca de tiros e Martínez foi atingido por um policial, não resistindo aos ferimentos e vindo a falecer (BANDEIRA 1980). 
revolta dos trabalhadores veio do Rio de Janeiro. Nas comemorações do $1^{\circ}$ de Maio, o movimento trabalhista do estado convocou uma greve geral que também foi seguida por São Paulo. Nesse ponto, o movimento grevista já se espalhara também para Bahia e Pernambuco. O Conselho Geral dos Operários, organização criada no lugar do COB, fechado durante as manifestações de 1917, apresentou as reivindicações dos grevistas:

1 - dia de oito horas de trabalho; 2 - repouso semanal ininterrupto de 36 horas; 3 - proibição do trabalho dos menores de 14 anos e do trabalho noturno das mulheres; 4 - estabelecimento do salário mínimo, baseado sobre o custo atual dos víveres e pagamentos efetuados semanalmente; 5 - igualdade do salário das mulheres ao dos homens; 6 - completo respeito por parte dos poderes públicos às associações operárias e plena liberdade de pensamento; 7 - baixa efetiva e segura dos gêneros de primeira necessidade. Deve-se organizar-se um conselho de alimentação fiscalizado pelas associações populares, aos quais deverão ser concedidos os direitos de requisição; 8 - Confiar ao conselho de alimentação o encargo de impedir a falsificação dos gêneros de primeira necessidade; 9 - redução imediata dos aluguéis. (BANDEIRA; MELO; ANDRADE, 1980, p. 174).

As reivindicações foram respondidas com repressão e prisões. Mesmo assim, em São Paulo, a greve alcançou Campinas, Sorocaba, Ribeirão Preto, Jundiaí, Itu e Cruzeiro. O presidente do estado foi, então, pressionado a libertar os grevistas presos e firmar acordo com os patrões, garantindo a jornada de 8 horas de trabalho em toda a região. Os trabalhadores de São Paulo foram os primeiros a conseguirem essa conquista no Brasil. Os outros movimentos grevistas viram a conquista dos paulistas como um sinal e intensificaram a greve. O governo do Brasil convocou uma comissão no Congresso, para promulgar as primeiras leis sociais do país, aprovando a jornada de 8 horas diárias, para todo o território, em documento conhecido com Código de Trabalho, que garantia: 
$1^{\circ}$ direito de associação; $2^{\circ}$ menores de 14 anos não serão admitidos em trabalhos na indústria e comércio; entre 14 e 18 somente trabalhos leves sem prejuízo para a educação profissional em geral; $3^{\circ}$ salário igual sem distinção de sexo; $4^{\circ}$ repouso hebdomadário; $5^{\circ}$ oito horas de trabalho por dia ou 48 horas semana; $6^{\circ}$ estrangeiros legalmente admitidos terão direito ao mesmo tratamento dos nacionais; $7^{\circ}$ todos os Estados organizarão serviços de inspeção do trabalho, o qual deverá compreender também as mulheres. (PESSOA apud BANDEIRA; MELO; ANDRADE, 1980, p. 175).

O governo tentava seguir a orientação das potências vencedoras da Primeira Guerra que haviam percebido que, para evitar novas revoluções, teriam que aprovar algumas reivindicações dos trabalhadores. Obviamente, parte da burguesia brasileira relutou em aceitar os termos e os trabalhadores tiveram que continuar em luta nas décadas seguintes, para garantir a efetivação das conquistas, mas é inegável que foi através da fusão das reivindicações do proletariado brasileiro com a conjuntura provocada pela Revolução Russa que se alcançou um novo patamar de luta e organização da classe.

Esta ligação do movimento operário brasileiro com os acontecimentos de 1917 nos parece deveras importante e é preocupante seu desaparecimento no senso comum, que identificamos nos participantes de nossos cursos. Muito ajudou nessa ocultação a própria imprensa da época que deturpou tanto as notícias vindas da Rússia como as das mobilizações no Brasil. A imprensa de hoje também não parece ter interesse em resgatar essa história. Reafirmamos que isso não é por acaso e corresponde a uma construção ideológica das classes dominantes que, desde 1917, perceberam o perigo que pode ser a classe trabalhadora conhecer sua própria história. 


\section{CONSIDERAÇÕES FINAIS}

Identificamos, a partir de inquietações surgidas em cursos ofertados sobre a história da Revolução Russa, as características de um determinado senso comum de caráter ideológico sobre o evento histórico. Além disso, vimos seu desdobramento num esquecimento da relação entre a Revolução e o movimento operário brasileiro. Resta-nos agora tirar algumas conclusões provisórias sobre o assunto.

Parece-nos que a Revolução continua uma questão atual, para os trabalhadores do país se libertarem de suas condições penosas de vida. De uma lado, temos um capitalismo altamente desenvolvido em termos de relações capitalistas, com uma burguesia que adquire uma faceta imperialista em outros países (Paraguai, Bolívia, Haiti e etc.). ${ }^{15}$ Por outro lado, temos uma classe trabalhadora imensa que assiste suas condições de vida se deteriorar. Em meio às crises periódicas do sistema capitalista, a classe dominante brasileira tem retirado direitos dos trabalhadores, que foram conquistados com muito esforço. Estes cortes nos direitos básicos têm como objetivo diminuir os salários e aumentar os lucros das empresas.

O resgate da estratégia revolucionária pode poupar a organização dos trabalhadores e nutrir esperanças de que a gerência do Estado seria opção para resolver suas necessidades. O ciclo de lutas capitaneado pelo PT/CUT mostrou a falha dessa tentativa de priorizar a luta nos espaços institucionais, principalmente, porque desarmou os trabalhadores de sua combatividade, transformando-os em um exército de eleitores, indefesos para o momento em que vivemos, de avanço dos ataques à classe operária.

As lições da Revolução Russa apenas serão aproveitadas se acompanhadas de uma crítica ao senso comum sobre essa experiência. Apenas na crítica a essas impressões, ao seu caráter fragmentário, bizarro, incoerente e sua ligação com as ideias dominantes é que podemos resgatar toda a riqueza daquele evento histórico. Como experiência de luta, a Revolução de 1917 reafirmou que tanto o idealismo quanto o pragmatismo intelectual não

15 Fontes (2010) traz argumentos sobre essa afirmação. 
são suficientes para encarar um possível processo revolucionário, em nosso país, com suas complicações dramáticas. É preciso sempre fazer uma análise concreta de uma situação concreta (MARX,1982). Isso significa que somente a leitura das contradições reais poderá guiar-nos no que tange à estratégia mais acertada para a conquista e a manutenção de uma revolução.

No caso brasileiro, o movimento que viveu influenciado sobre os fatos de 1917 desenvolveu um grau altíssimo de combatividade e ameaçou a ordem, chegando a tomar o poder na principal cidade do país, por alguns dias. Isso mostra a força devastadora que a organização trabalhista nacional pode alcançar se perceber que é herdeira de uma tradição internacional de luta da classe por melhores condições de vida, cuja Revolução de 1917 foi um dos bastiões. Resgatar a experiência soviética sem dogmatismo ou romantismo é tarefa fundamental, para tirarmos as lições necessárias para retomar as rédeas da história para as mãos daqueles que tudo produzem.

\section{REFERÊNCIAS}

BANDEIRA, M.; MELO, C.; ANDRADE, A. T. O ano vermelho: a Revolução Russa e seus reflexos no Brasil. São Paulo: Brasiliense, 1980.

GRAMSCI, A. Cadernos do cárcere. v. 1 - 6. Rio de Janeiro: Civilização Brasileira, 2002.

FONTES, V. O Brasil e o capital-imperialismo: teoria e história. Rio de Janeiro: Editora UFRJ, 2010.

HOBSBAWM, E. A Era dos Extremos. São Paulo: Companhia das Letras, 1997.

IASI, M. Senso Comum e Conservadorismo: o PT entra o senso comum e a desconstrução da consciência. Blog da Boitempo, Rio de Janeiro, 25 abr. 2013. Disponível em: <https://blogdaboitempo.com.br/2013/04/25/ senso-comum-e-conservadorismo-o-pt-e-a-desconstrucao-daconsciencia/>. Acesso em: 30 jan. 2017

LENIN, V. O Estado e a Revolução. São Paulo: Hucitec. 1983.

Imperialismo, estágio superior do capitalismo. São Paulo: Expressão Popular, 2012. 
LOUREIRO, I. A revolução alemã (1918-1923). São Paulo: Editora da Unesp, 2005.

MARX, K. Contribuição à crítica da Economia Política. São Paulo: Abril, 1982.

Crítica do Programa de Gotha. São Paulo: Boitempo, 2012.

O Capital. São Paulo: Civilização Brasileira, 2014.

MARX, K.; ENGELS, F. A ideologia alemã: crítica da mais recente filosofia alemã em seus representantes Feuerbach, B. Bauer e Stirner e do socialismo alemão em seus diferentes profetas (1845-46). São Paulo: Boitempo, 2012.

MEYER, V. Ernesto Martins, Érico Csaczkes Sachs. In: POLOP: Uma trajetória de luta pela organização independente da classe operária no Brasil. Salvador: Centro de Estudos Victor Meyer, 2010. p. 15 - 20. Disponível em: <http://centrovictormeyer.org.br/wp-content/uploads/2010/04/ Polop-Uma-trajetoria-de-lutas.pdf>. Acesso em: 30 jan. 2017.

REED, J. Dez dias que abalaram o mundo. Lisboa: Avante, 1967.

REIS FILHO, D. A. A Revolução Russa, 1917-1921. São Paulo: Brasiliense, 1999.

SACHS. E. Qual a herança da Revolução Russa?. In: STOTZ, E.; WARTH, S. (orgs.). Conquistas e Impasses do Socialismo. Rio de Janeiro: Centro de Estudos Victor Meyer, 2011.p. 115 - 181. Disponível em: <http:// centrovictormeyer.org.br/wp-content/uploads/2012/06/Conquistas-eimpasses-do-socialismo.pdf>. Acesso em: 30 jan. 2017. 